\title{
Sorbed Anthracene Degradation by Sophorolipid Producing Yeasts
}

\author{
M. Cristina Romero ${ }^{1,4, *}$, Juan C. Chiaravalli ${ }^{2}$ and Enso H. Reinoso ${ }^{3}$
}

${ }^{1}$ Cát. Micología Médica e Industrial, Depto. Microbiología, Fac. Cs. Veterinarias, UNLP; ${ }^{2}$ Cát. Zootecnia General, Depto. Producción, Fac. Cs. Veterinarias, UNLP; ${ }^{3}$ Cát. Micología Médica e Industrial, Depto. Microbiología, Fac. Cs. Veterinarias, UNLP; ${ }^{4}$ CONICET Researcher, La Plata, Argentina

\begin{abstract}
The organic pollutan adsorption/desorption process by microbial degradation had been less studied than metal ones. The sorption assays alone did not predict desorption, due to hysteresis, irreversibility, fixed compounds in different sites, with diverse desorption rates. Most of the studies dealt with bacteria rather than filamentous fungi and yeasts. So, our aims were to isolate yeasts from polluted sediments, to quantify its potential to uptake anthracene (An) and to evaluate the bioavailability by a desorption model. Yeasts were isolated from hydrocarbon-polluted samples, 40isolates grew in anthracene-plates. Molecular characterization was achieved by sequence analysis of the ITS1-5.8S rRNA-ITS4 and 26S rRNA regions; morphological and physiological determination were also done. Candida parasilopsis, Pichia anomala and Rhodothorula mucilaginosa were the prevalent yeasts. An-degradation was assessed in soilsystems with $0,50,100,150,200$ and $250 \mu \mathrm{g} \mathrm{An/l,} 3$ differentes sorbens types, organic carbon, organic nitrogen, PAHs, sand:silt:clay, $\mathrm{pH}$ and cation exchange capacity. Sophorolipids excretion were confirmed by HPLC, UV-detector with active fraction at $9.669 \mathrm{~min}$ (RT $9.646 \mathrm{~min}=$ sophorolipid-standard). A desorption model with equilibrium, nonequilibrium and nondesorption areas, was applied to explain the experimental data, An-transformation was greater in the organic liquid-phase than in the soil-sorbed ones; the desorption-coefficients and soil components were negatively correlated with the kinetic parameters. The An-release depended on the sophorolipid excretion, soil matrix and particles sizes. Desorption parameters significantly fitted the yeast uptake, with $\mathrm{R}^{2}=0.97, \mathrm{R}^{2}=0.90$ and $\mathrm{R}^{2}=0.97$ for C. parasilopsis, $P$. anomala and $R$. mucilaginosa, respectively.
\end{abstract}

Keywords: Anthracene, bioavailability, biodegradation, Candida parasilopsis, desorption model Pichia anomala, Rhodothorula mucilaginosa, sophorolipid.

\section{INTRODUCTION}

Polycyclic aromatic hydrocarbons (PAHs) accumulate in nature because release rates from industrial effluents exceeded dissipation rates, chemical and microbial transformation [1,2]. Low biodegradation had been attributed to diverse factors, such as surface soil and effluent properties, chemical toxicity, pollutant concentrations and low availability of the toxicants [3-5]. Soil-sorbed PAHs had been considered unavailable for biotransformation without prior desorption, so microorganisms must uptake sorbed molecules or facilitate desorption by surfactant production $[6,7]$.

Yeasts secret different biosurfactants, like sophorolipids (SLP), liposan, carbohydrat-protein-lipid complex, mannoprotein, mannosylerythritol, erythritol and mannose-lipids $[8,9]$. SLP are the most promising ones, due to its low toxicity, high biodegradability, excreted in great amounts, low foam formation, high detergency, selective and specific activity at wide range of temperature, $\mathrm{pH}$ and salinity, produced from renewable sources or industrial residues, easy to recover $[10,11]$

*Address correspondence to this author at the Cát. Micología Médica e Industrial, Depto Microbiología, Fac. Cs. Veterinarias, UNLP. Calle 60 e/ 119 y 120, s/nro, La Plata, Argentina; Tel: 0054-221-155656334;

E-mail: cmriar@yahoo.com.ar
The organic pollutant adsorption/desorption had been less studied than to metal process $[12,13]$. Sorption tests did not predict desorption responses, due to hysteresis, irreversibility of the process, and fixed compounds in compartments with different desorption rates [14-16]. Most of the studies dealt with bacteria rather than filamentous fungi and yeasts, therefore, our aims were to isolate yeasts from polluted sites, to quantify the anthracene (An) uptake by cometabolism, to evaluate the An-bioavailability and to obtain the desorption parameters.

\section{MATERIALS AND METHODS}

\section{Sampled Sites and Yeasts Isolation and Identification}

Yeasts were isolated from sediment samples taken from the industrial area, La Plata, Argentina. Total organic carbon (TOC), total organic nitrogen (TON; CHN analyzer, Perkin-Elmer, Norwalk, CT) and polycyclic aromatic hydrocarbons (PAHs, FTIR-PerkinElmer), sand:silt:clay proportions, $\mathrm{pH}$ and cation exchange capacity (CEC $(\mathrm{cmol} / \mathrm{kg})$ of the sediments were determined (Table 1) [17].

Yeasts were isolated under selective conditions in agar-mineral medium (MM, [18]) with $75 \mu \mathrm{g} \mathrm{An/l} \mathrm{as} \mathrm{C-}$ source. They were characterized by colony, cell morphologies, assimilation, physiological differences, 
Table 1: Characteristics of the Soils Used in the An-Degradation Experiments

\begin{tabular}{|c|c|c|c|c|c|c|}
\hline & $\begin{array}{c}\text { TOC } \\
\text { (mg/kg soil) }\end{array}$ & $\begin{array}{c}\text { TON } \\
\text { (mg/kg soil) }\end{array}$ & $\begin{array}{c}\text { PAHs } \\
\text { (mg/kg soil) }\end{array}$ & sand:lime:clay & pH & $\begin{array}{c}\text { CEC } \\
\text { (cmol/kg) }\end{array}$ \\
\hline \hline soil I & 9.8 & 4.3 & 102.1 & $47: 21: 32$ & 5.5 & 7.10 \\
\hline soil II & 5.6 & 2.0 & 84.6 & $58: 15: 25$ & 5.9 & 24.40 \\
\hline soil III & 4.5 & 1.2 & 40.7 & $48: 28: 24$ & 6.0 & 33.00 \\
\hline
\end{tabular}

D-glucuronate, reproduction and coenzyme Q-system by HPLC [19].

Yeasts were identified by sequencing two different rRNA genes and DNA isolation [20]. The amplifications were performed with Corbett Cool Gradient Palm Cycler CGI-96: DNA strands were sequenced by $A B I$ 3130XL automated sequencer (Applied Biosystems, USA) of ITS1-5.8S rRNA-ITS4 and 26S rRNA regions. PCR amplicons were synthesized using primers, Fermentas, Germany). Amplification was performed for 40 PCR cycles, denaturation at $95^{\circ} \mathrm{C}$ for $2 \mathrm{~min}$, annealing at $58^{\circ} \mathrm{C}$ for $2 \mathrm{~min}$, and extension at $72^{\circ} \mathrm{C}$ for $2 \mathrm{~min}$, final extension for $10 \mathrm{~min}$. For $26 \mathrm{~S}$ rRNA, the primers NL1 (5'-GCA TAT CAA TAA GCG GAG GAA AAG-3') and NL4 (5'-GGT CCG TGT TTC AAG ACG G-3') were used for amplifications, for 35 PCR cycles with denaturation at $95^{\circ} \mathrm{C}$ for $1 \mathrm{~min}$, annealing at $58^{\circ} \mathrm{C}$ for $1 \mathrm{~min}$, and extension at $72^{\circ} \mathrm{C}$ for $2 \mathrm{~min}$, final extension for $10 \mathrm{~min}$. Sequences were compared by BLASTN and aligned with related species sequences $[21,22]$.

\section{Anthracene Degradation Assays}

Three yeast species were selected for this assays, due to its conspicuous development in An-plates. They were precultivated in $50 \mathrm{ml}$ Sabouraud for $48 \mathrm{~h}$, at $28^{\circ} \mathrm{C}, 2$ days, till exponential growth to accumulate enough internal-C reserves. Then, $1 \mathrm{ml}$ yeast suspension were inoculated in 6 flasks with $100 \mathrm{ml} \mathrm{MM}$ plus $0,50,100,150,200,250 \mu \mathrm{g} A n / l ~ M M ~ a n d ~ 2 \%$ $\mathrm{C} 16, \mathrm{pH} 5.4$, by triplicate. After 15 days incubation time at $28^{\circ} \mathrm{C}$ and $180 \mathrm{rpm}$, cells were centrifugated $(5000 \mathrm{~g}$, $5 \mathrm{~min}$ ), washed twice with sterile $\mathrm{MM}$, and resuspended in MM to an optical density (OD) $600 \mathrm{~nm}$, by triplicate.

Yeast cell concentration (cells $/ \mathrm{ml}$ ), dry cellular weight (DCW, $g / l$ ) and OD600 were obtained subsampling at $0,1^{\text {st }} ., 2^{\text {nd }} ., 3^{\text {rd }} ., 4^{\text {th }} ., 5^{\text {th }} ., 7^{\text {th }} ., 10^{\text {th }} ., 13^{\text {th }}$. and $15^{\text {th }}$ days. A correlation curve was plotted with OD600 and DCW against cell concentration. A correction factor 1.0-1.3 was used for NucleoCounter ${ }^{\circledR}$ YC-100. Correlation between OD, DCW and yeast cell count was 1 OD600, within linear range ca. 0.3-0.6 g DCW $/=$ ca. $1 \times 10^{6}$ to $5 \times 10^{6}$ cells $/ \mathrm{ml}$.

Simultaneously, $1 \mathrm{ml}$ of each flask were subsampled to obtain An-levels by HPLC (HewlettPackard, Bad Homburg, Germany), apparatus 1050 M equipped with a quaternary pump system, a diode array detector $1040 \mathrm{M}$ series $\mathrm{I}$, and an HP Chemstation. The separation was achieved with a LiChroCart 125-4 RP-18 end-capped (5 mm) column (Merck, Darmstadt, Germany). The initial solvent composition was $30 \% \mathrm{CH}_{3} \mathrm{OH}-70 \% \mathrm{H}_{3} \mathrm{PO}_{4}(0.1 \%)$, reaching $100 \%$ methanol after $14 \mathrm{~min}$ at a flow rate of 1 $\mathrm{ml} / \mathrm{min}$. The UV-visible absoption spectra of degradation products were analizsed by a diode array detector, in triplicate $[12,23]$. The chemicals, An and solvents were purchased by Aldrich-Chemie, and were of the highest purity available.

\section{An-Desorption Assays}

Different sterilized soils were used to obtain the desorption factors (Table 2). The assays were carried out in $100 \mathrm{ml}$ tubes with $30 \mathrm{ml}$ sterile soils plus $2 \mathrm{ml}$ sterile phosphate buffer plus $1 \mathrm{ml}$ inoculumn yeasts, $100 \mu \mathrm{g} \mathrm{An} / \mathrm{MM}$ and $2 \% \mathrm{C} 16, \mathrm{pH}$ 5.4. Tubes were incubated at $180 \mathrm{rpm}, 15$ days, in darkness, at $28^{\circ} \mathrm{C}$. At the $15^{\text {th }}$. day, the tubes were centrifugated, to separate sediments from supernatants, and An-final levels were determinated in sorbed and liquid phases by HPLC. Three controls were incubated in the same conditions, one inoculated but without soil, other inoculated with 30 $\mathrm{ml}$ soil suspension and then sterilized, the $3^{\text {rd }}$. one uninoculated with $30 \mathrm{ml}$ soil suspension.

Once a day, $1 \mathrm{ml}$ subsamples were withdrawn from each tube to quantify unsorbed and fixed An-levels, yeast cell concentration, DCW and OD600. Initials Anconcentrations were determined in soil samples and controls. All the subsamples were analized by triplicate.

Biosurfactant presence were obtained from the same An-degradation cultures by surface tension (ST) measurements. Cells harvested in late log phase were washed twice with $20 \mathrm{mM}$ phosphate buffer, 
resuspended in $20 \mathrm{mM}$ phosphate buffer plus $10 \mu \mathrm{M}$ EDTA, placed in a U-shaped tube to be observed by microscopy. Uninoculated tubes were used as controls, all the measurements were made by triplicate.

Subsamples were taken and extracted with ethylacetate to determine their oil-displacement activities, and kept for the HPLC linear gradient with UV detector system. The most active fraction eluted was obtained at RT $9.669 \mathrm{~min}$; standard sophorolipids showed a peak at RT $9.646 \mathrm{~min}, \mathrm{~m}=\mathrm{z}$ of 648.760 and 650.816 were found. $M / Z$ of 648.760 corresponded to a sodium adduct of $\mathrm{C} 18$ sophorolipid which is added $23 \mathrm{Da}$ of the sodium molecule, whereas the $\mathrm{m}=\mathrm{z}$ of 650.816 corresponded to C20:1 sophorolipid $[24,25]$.

\section{Data Analysis}

The experimental data were analyzed by ANOVA, and fitted to the model by Quasi-Newton Technique, and SAS guide. The regression analysis $\left(R^{2}\right)$ expressed the goodness of the results.

\section{RESULTS}

The isolates were identified as Candida batistae, Candida bombicola, Candida glabrata, Candida guillermondi, Candida maltosa, Candida sphaerica, Candida parasilopsis, Cryptococcus albidus, Cryptococcus diffluens, Pichia anomala, Pichia kudriavzevii, Rhodotorula bogoriensis, Rhodotorula glutinis, Rhodotorula mucilaginosa and Saccharomyces cerevisiae. $C$. parasilopsis, $P$. anomala and $R$. mucilaginosa were frequent in the An-plates, so they were selected for this study. They were identified using amplification and sequencing of the Internal Transcribed Spacer ITS1 and ITS4 region of ribosomal DNA (rDNA) (Table 3). ITS-region is short, readily amplified by PCR using universal single primer pairs complementary to conserved regions. Morphological and physiological characterization of the isolations accorded (ca. $78 \%$ ) with the sequence analysis.

Biphasic cultures, with soluble and particulate An, were similar to environmental situation than one-phase ones; moreover, pollutants settled in equilibrium, nonequilibrium and nondesorption areas. In nondesorption sites, toxicants did not discharge to solution, nonequilibrium area showed a proportional release rate between solid and liquid phases, and in the equilibrium ones An-particles dissolved in the liquid.

The three-site desorption model fitted the experimental data, being the parameters and site fractions representative of yeast uptake (Figure 1). A first-order kinetics was observed in the $C$. parasilopsis and $R$. mucilaginosa assays, with a $\mathrm{Km}$ value $=0.0375$ $\min ^{-1}\left(R^{2}=0.97\right)$ and $\mathrm{Km}=0.0450 \mathrm{~min}^{-1}\left(R^{2}=0.98\right)$, respectively, while $P$. anomala cultures followed Michaelis-Menten kinetics with a $\mathrm{Km}=0.0740 \mathrm{~min}^{-1}\left(\mathrm{R}^{2}\right.$ $=0.95) \mathrm{Km}$ value assessed the yeasts affinity for the substrate, so in $C$. parasilopsis and $R$. mucilaginosa experiments higher An-degradation would be expected, in relation to $P$. anomala.

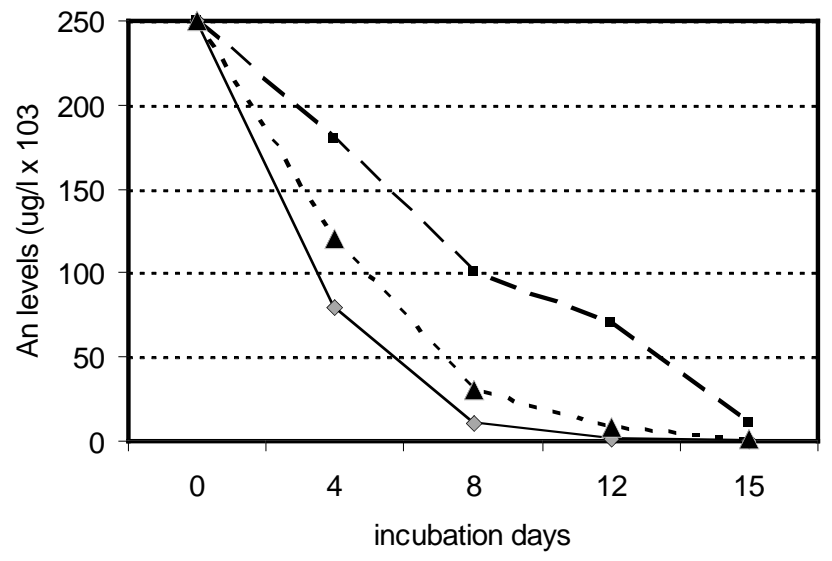

$\checkmark$ C.parasilopsis — - P. anomala - - - - R.mucilaginosa

Figure 1: An-biodegradation curves in $C$. parapsilopsis, $P$ anomala and $R$. mucilaginosa in liquid phase.

Equilibrium (Seq) partitioning was described by Seq $=f$ eq $\mathrm{K}_{\mathrm{F}} \mathrm{Ce}^{\mathrm{n}}$; nondesorption (Snd) responded to Snd = fnd $K_{F} C^{n}$; and nonequilibrium (Sneq) sites followed the relation: $d$ Sneq / $d t=\alpha\left(\right.$ fneq $K_{F} C^{n}-$ Sneq). In the equation $\mathrm{K}_{\mathrm{F}}$ was the Freundlich sorption coefficient, $\mathrm{n}$ : isotherm curvature constant, $\mathrm{C}$ : An liquid-phase concentration (mg/ l), Ce: An liquid-phase concentration $(\mathrm{mg} / \mathrm{l})$ in sorption equilibrium, $\mathrm{t}$ : desorption time $(\min ), \alpha$ : $1^{\text {st }}$. order desorption rate coefficient $\left(\mathrm{min}^{-1}\right)$ for nonequilibrium areas, feq, fneq and $f$ nd: were equilibrium, nonequilibrium and nondesorption fractions, Seq, Sneq and Snd were Ansorbed levels $(\mathrm{mg} / \mathrm{kg})$ in the equilibrium, nonequilibrium and nondesorption areas, respectively (Table 4). $\mathrm{K}_{\mathrm{F}}$ and $\mathrm{n}$ were obtained from the sorption isotherm, $f \mathrm{nd}$ was the plateau of the desorption profile, while $f$ neq, $f$ eq and a were calculated by nonlinear regression analysis of the desorption experimental data, for each yeasts cultures.

The profiles confirmed that the three processes occurred; equilibrium was confirmed by the An-levels in the liquid phase; An did not increase although its molecules were liberated from soil particles due to fungal degradation. More An was sorbed to soils with 
Table 2: An-Desorption Parameters Obtained by the Three-Site Model. (Data are the Arithmetic Mean of the Three Yeasts Cultures for Each Soil Type; \pm SD)

\begin{tabular}{|c|c|c|c|c|c|}
\hline & feq & fneq & fnd & $\alpha\left(\mathbf{m i n}^{-1}\right)$ & $\mathbf{R}^{2}$ \\
\hline \hline soil I & $0.35( \pm 0.009)$ & $0.33( \pm 0.010)$ & $0.35( \pm 0.005)$ & $0.0020( \pm 0.003)$ & 0.97 \\
\hline soil II & $0.43( \pm 0.008)$ & $0.38( \pm 0.008)$ & $0.20( \pm 0.008)$ & $0.0025( \pm 0.004)$ & 0.96 \\
\hline soil III & $0.75( \pm 0.011)$ & $0.41( \pm 0.009)$ & $0.10( \pm 0.010)$ & $0.0027( \pm 0.009)$ & 0.90 \\
\hline
\end{tabular}

higher TOC, TON and PAHs contents (Table 1); so more An desorption could be expected (Figure 2). The An-feq ranged from $0.35,0.43$ and 0.75 ; fneq were similar among soil types $(0.33 ; 0.38,0.41)$ (Table 3 ), and $f$ nd decreased as TOC, TON and PAHs increased, ranging from $0.35,0.20$ and 0.10 .

Moreover, An-sorbed to particles by photodimerization under shear stress, formed a complex solid with 2 An-molecules, a reversible process. Desorption coefficients $\alpha\left(\mathrm{min}^{-1}\right)$, were consistent with the interactions between soil constituents, yeasts presence, pollutant levels and availability, and were negatively correlated with the kinetic parameters, $\mathrm{Km}$ and maximum degradation rate (Vmax).

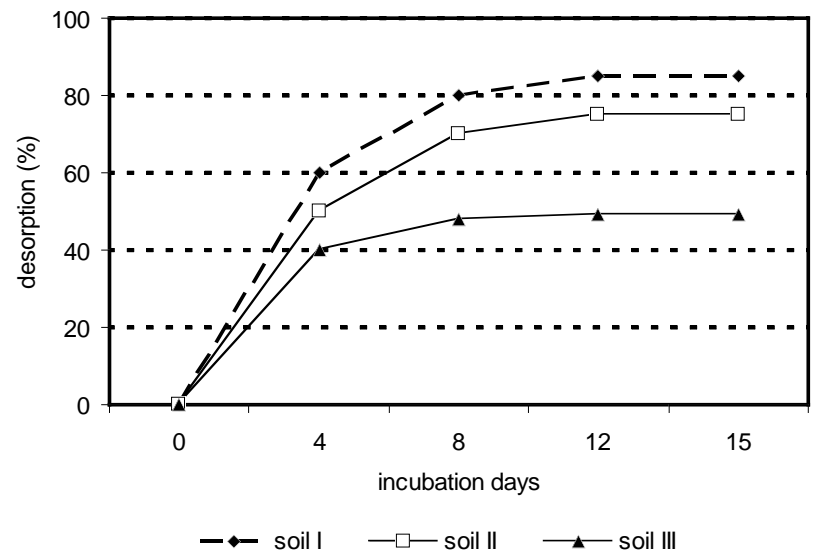

Figure 2: An-desorption (\%) during the desorption assays for the different soil types.

An-liberation depended more on the yeast surfactant excreted, than to soil particles to which they were bound. The $1^{\text {st }}$. condition explained the Anavailability of this study, confirmed by the surface tension measurements, by other hand, the $2^{\text {nd }}$. process, called direct-uptake, was not significant.

The ST differences between controls and yeasts cultures indicated that biosurfactants presence. From thermodynamics view, ST was the excess of free energy/unit area in the interface liquid-vapour interface. The van der Waals interactions were $0.027 \pm 0.004$; $0.031 \pm 0.005$ and $0.058 \pm 0.004 \mathrm{~N} / \mathrm{cm}^{2}$, for $C$. parasilopsis, $R$. mucilaginosa and $P$. anomala, respectively. ST was the integrating anisotropic tangential stress along the perpendicular direction to the interface An-media and air-flask, depended on temperature, composite media, An-levels and yeasts densities. SLP was liberated to the medium as extracellular carbon storage, as secondary metabolites and did not have function for cellular growth, development and reproduction $[5,26]$.

Different fungal mechanisms determined the bioavailability of organic soil-sorbed pollutants, like: biosurfactants production, extracellular enzymes excretion, cometabolism, high substrate affinity (low $\mathrm{Km})$, high Vmax and cell adhesion to particles [27-29]. SLP had been especially reported in Candida spp. and Rhodothorula spp. cultures [30-32], in accordance with our results, and PAHs-degradation was in relation to its metabolic abilities [33].

Yeasts are preferred than others microorganisms for biosurfactants due to their GRAS (generally regarded as safe) status, that is, they do not induce

Table 3: Sequence Analysis to Identify the Yeast Species by ITS Regions

\begin{tabular}{|c|c|c|c|c|}
\hline yeast species & primer sequence & product size & $\begin{array}{l}\text { annealing } \\
\text { temperature }\end{array}$ & $\%$ agreement \\
\hline P. anomala & $\begin{array}{l}\text { 5'-ACGTCATAGAGGGTGAGAAT-3' } \\
\text { 5'-AAACACCAAGTCTGATCTAATG-3' }\end{array}$ & $197 \mathrm{bp}$ & 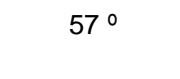 & 97.5 \\
\hline C. parapsilopsis & $\begin{array}{l}\text { 5'-GAGGGTGTCAGTTCTTTGT-3' } \\
\text { 5'-GTGAGCTGCGAGAGTC-3' }\end{array}$ & $224 b p$ & $56^{\circ}$ & 96.5 \\
\hline R. mucilaginosa & $\begin{array}{l}\text { 5'-GCGCTTTGTGATACATTTTC-3' } \\
\text { 5'-CCATTATCCATCCCGGAAAA-3' }\end{array}$ & $169 \mathrm{bp}$ & $54^{\circ}$ & 95.0 \\
\hline
\end{tabular}


Table 4: The An-Sorption Parameters by each Yeast Assays ((Data are the Arithmetic Mean of the Thre Yeasts Cultures for Each Soil Type; \pm SD)

\begin{tabular}{|c|c|c|c|c|c|}
\hline & \multicolumn{3}{|c|}{ Freundlich equation } & \multicolumn{2}{|c|}{ linear equation } \\
\hline & $K_{F}[(\mathrm{mg} / \mathrm{kg}) /(\mathrm{mg} / \mathrm{l})]$ & $n$ & $\mathbf{R}^{2}$ & $\mathrm{Kd}(\mathrm{l} / \mathbf{k g})$ & $\mathbf{R}^{2}$ \\
\hline soil I & 1.44 & 1.02 & 0.99 & 1.50 & 0.98 \\
\hline soil II & 3.18 & 1.05 & 0.98 & 3.40 & 0.99 \\
\hline soil III & 12.40 & 0.93 & 0.99 & 11.90 & 0.98 \\
\hline
\end{tabular}

toxicity or pathogenic reactions. Yeasts produce biosurfactants in higher concentrations, faster growth rate than filamentous fungi, resistant to unfavorable environments, useful in biological treatment of effluents and PAHs degradation [34,35]. Candida albicans [31], Candida bombicola [30,36], Candida batistae [37], Candida glabrata [38], Candida kuoi [39], Candida tropicalis [26,27], Pichia anomala [2,40], Hansenula angusta [17], Rhodotorula bogoriensis [32,41], Rhodotorula minuta [17], Rhodotorula glutinis [33,42] and Wickerhamiella domercqiae $[43,44]$ had been confirmed as SLP producers.

Biosurfactant physiological roles are not completely elucidated, a generalization is difficult because they presented different chemical structures and superficial properties $[45,46]$. Therefore, each biosurfactant could perform diverse functions, providing a wide range of advantages for microorganisms in its ecological niches [47-49]. However, the use of biosurfactants in bioremediation and the optimization of large-scale production is needed, as well as studies of alternative C-sources derived from agroindustrial wastes [50-52].

In conclusions, it is important to evaluate the possible in-situ production in polluted sites to speed up soil restoration, to isolate wild microorganisms that excreted biosurfactant, to study the factors and conditions to optimize biosurfactant production and use in field studies. Like any important subject in science, there are more questions than answers; research in biosurfactants for use in in-situ bioremediation of polluted sites is still an innovative subject that needs more reliable scientific data.

\section{ACKNOWLEDGEMENTS}

This work was supported by grants from the National Council of Scientific and Technological Research - CONICET, and from the National University of La Plata (UNLP), Fac. Ciencias Veterinarias, Cátedra de Micología Médica e Industrial, Argentina.

\section{REFERENCES}

[1] Thapa B, Kumar A, Ghimire A. A review on bioremediation of petroleum hydrocarbon contaminants in soil. Kathmandu Univ J Sce Engineer Technol 2012; 8: 164-70. http://dx.doi.org/10.3126/kuset.v8i1.6056

[2] Pan F, Yang Q, Zhang Y, Zhang S, Yang M. Biodegradation of polycyclic aromatic hydrocarbons by Pichia anomala. Biotech Lett 2004; 26: 803-6. http://dx.doi.org/10.1023/B:BILE.0000025882.33234.91

[3] USEPA Priority Chemicals (PCs), 2011, http://www.epa.gov/ osw/hazard/wastemin/priority.html

[4] Romero MC, Hammer E, Cazau MC, Arambarri AM Selection of autochthonous yeast strains able to degrade biphenyl. W J Microb Biotech 2001; 17: 591-4. http://dx.doi.org/10.1023/A:1012462906663

[5] Evans GG, Furlong J. Environmental biotechnology: theory and application. 2nd. ed. John Wiley \& Sons; 2011.

[6] Sáenz-Marta $\mathrm{Cl}$, Ballinas-Casarrubias ML, Rivera-Chavira BE, Nevárez-Moorillón GV. Biosurfactants as useful tools in bioremediation. In: Shiomi editor. Advances in bioremediation of wastewater and polluted soil. 2nd ed. Tech Publish 2015; pp. 94-109.

http://dx.doi.org/10.5772/60751

[7] Konishi M, Maruoka N, Furuta Y, Morita T, Fukuoka T, Imura T, Kitamoto D. Biosurfactant-producing yeasts widely inhabit various vegetables and fruits. Biosc Biotech Biochem, Microbiol Ferment Technol 2014; 78: 516-23.

http://dx.doi.org/10.1080/09168451.2014.882754

[8] Kurtzman CP, Fell JW, Boekhout T. The Yeasts: a taxonomic study. 5th ed. London: Elsevier Science; 2011.

[9] Robert V. Methods for isolation, phenotypic characterization and maintenance of yeasts. In: Kurtzman CP, Fell JW, Boekhout T editors. The yeasts, a taxonomic study, 5th. ed. Elsevier, 2011; pp. 87-110.

[10] Kang SW, Kim YB, Shin JD, Kim EK. Enhanced biodegradation of hydrocarbons in soil by microbial biosurfactant, sophorolipid, Appl Biochem Biotech 2010; 160: 780-90. http://dx.doi.org/10.1007/s12010-009-8580-5

[11] Nguyen TTL, Sabatini DA. Characterization and emulsification properties of rhamnolipid and sophorolipid biosurfactants and their applications. Internat $\mathrm{J}$ Molec Sc 2011; 12: 1232-44. http://dx.doi.org/10.3390/ijms 12021232

[12] Romero MC, Reinoso EH, Urrutia MI, Moreno Kiernan A. Biosorption of heavy metals by Talaromyces helicus: a trained fungus for copper and biphenyl detoxification. Elect $\mathrm{J}$ Biotech 2006; 9(3).

[13] Chakraborty S, Mukherjee A, Das TK. Biochemica characterization of a lead-tolerant strain of Aspergillus foetidus: an implication of bioremediation of lead from liquid media. Int Biodet Biodeg 2013; 84: 134-42. http://dx.doi.org/10.1016/j.ibiod.2012.05.031 
[14] Gadd GM. Biosortion: critical review of scientific rationale, environmental importance and significance for pollution treatment. J Chem Technol Biotechnol 2009; 84: 13-28. http://dx.doi.org/10.1002/jctb.1999

[15] Park JH, Zhao $X$, Voice TC. Biodegradation of nondesorbable naphthalene in soils. Environ Sci Technol 2001; 35: 2734-40.

http://dx.doi.org/10.1021/es0019326

[16] Park JH, Feng Y, Ji P, Voice TC, Boyd SA. Assessment of bioavailability by soil-sorbed atrazine. Appl Environ Microbiol 2003; 69: 3288-98.

http://dx.doi.org/10.1128/AEM.69.6.3288-3298.2003

[17] Romero MC, Urrutia MI, Reinoso EH, Moreno Kiernan A. Effects of the sorption/desorption process on the fluoranthene degradation by wild strains of Hansenula angusta and Rhodotorula minuta. Inter Resear J Microbiol 2011; 2: 230-6.

[18] Romero MC, Salvioli ML, Cazau MC, Arambarri AM. Pyrene degradation by filamentous soil fungi and yeast species. Environ Pollution 2002; 117: 159-63. http://dx.doi.org/10.1016/S0269-7491(01)00143-9

[19] Romero MC, Hammer E, Hanschke R, Arambarri AM, Schauer F. Biotransformation of biphenyl by filamentous fungi Talaromyces helicus. W J Microb Biotech 2005; 21: 101-06.

http://dx.doi.org/10.1007/s11274-004-2779-y

[20] Liu D, Coloe S, Baird R, Pederson J. Rapid mini-preparation of fungal DNA for PCR. J Clin Microbiol 2000; 38: 471.

[21] Corbaci C, Ucar FB, Yalcin HT. Isolation and characterization of yeasts associated with Turkish-style homemade dairy products and their potential as starter cultures. Afr J Microbiol Res 2012; 6: 534-42.

[22] Boz DT, Yalçın HT, Çorbacı C, Uçar FB. Screening and molecular characterization of polycyclic aromatic hydrocarbons degrading yeasts. Turkish J Biochem 2015; 40: 105-110.

[23] Romero MC, Urrutia MI, Reinoso EH, Moreno Kiernan M. Benzo[a]pyrene degradation by soil filamentous fungi. $\mathrm{J}$ Yeast Fung Resear 2010; 1: 25-29.

[24] Oliveira MR, Camilios-Neto D, Baldo C, Magri A, Celligoi MAPC. Biosynthesis and production of sophorolipids. Intern J Scientif. Tech Resear 2014; 3: 133-46.

[25] Imura T, Masuda Y, Minamikawa H, Fukuoka T, Konishi M, Morita T, Sakai H, Abe M, Kitamoto D. Enzymatic conversion of diacetylated sophorolipid into acetylated glucolipid: surface-active properties of novel bola form biosurfactants. $J$ Oleo Science 2010; 59: 495-501.

\section{http://dx.doi.org/10.5650/jos.59.495}

[26] Chandran P, Das N. Role of sophorolipid biosurfactant in degradation of diesel oil by Candida tropicalis. Bioremed $\mathrm{J}$ 2012; 16: 19-30.

http://dx.doi.org/10.1080/10889868.2011.628351

[27] Farag S, Soliman NA. Biodegradation of crude petroleum oil and environmental pollutants by Candida tropicalis strain. Braz Arch Biol Technol 2011; 54: 821-30. http://dx.doi.org/10.1590/S1516-89132011000400023

[28] Romero MC, Urrutia MI, Moreno Kiernan A. Sorptiondesorption response for perylene uptake by wild yeasts isolated from polluted sediments. Inter J Biol Pharma Allied Sci 2012; 1: 1411-21.

[29] Rivas FJ. Polycyclic aromatic hydrocarbons sorbed on soils: a short review of chemical oxidation based treatments. J Hazard Mat 2006; 138: 234-51. http://dx.doi.org/10.1016/j.jhazmat.2006.07.048

[30] Kurtzman CP, Price NPJ, Ray KJ, Kuo MT. Production of sophorolipid biosurfactants by multiple species of the Starmerella (Candida) bombicola yeast clade. FEMS Microbiol Letters 2010; 311: 140-6.

http://dx.doi.org/10.1111/j.1574-6968.2010.02082.x
[31] Basak G, Devlin D, Nilanjana D. Dual role of acidic diacetate sophorolipid as biostabilizer for $\mathrm{ZnO}$ nanoparticle synthesis and biofunctionalizing agent against Salmonella enterica and Candida albicans. J Microbiol Biotech 2013; 24: 87-96. http://dx.doi.org/10.4014/jmb.1307.07081

[32] Ribeiro IA, Bronze MR, Castro MF, Ribeiro MHL. Design of selective production of sophorolipids by Rhodotorula bogoriensis through nutritional requirements. J Molec Recog 2013; 25: 630-40.

http://dx.doi.org/10.1002/jmr.2188

[33] Zhang G, Frech WT, Hernandez R, Alley E, Paraschivescu $M$. Effects of furfural and acetic acid on growth and lipid production from glucose and xylose by Rhodotorula glutinis. Biom Bioener 2011; 35: 734-40. http://dx.doi.org/10.1016/j.biombioe.2010.10.009

[34] Hesham A, Wang Z, Zhang Y, Zhang J, Wenzhou L, et al. Isolation and identification of a yeast strain capable of degrading four and five ring aromatic hydrocarbons. Ann Microbiol 2006; 56: 109-120. http://dx.doi.org/10.1007/BF03174990

[35] Pulate VD, Bhagwat S, Prabhune AA. Microbial oxidation of medium chain fatty alcohol in the synthesis of sophorolipids by Candida bombicola and its physicochemical characterization. J Surf Deterg 2012; 16: 173-81. http://dx.doi.org/10.1007/s11743-012-1378-4

[36] Elshafie A, Al-Bahry SN, Al-Wahaibi YM, Al-Bemani AS, Joshi SJ, Al-Maqbali D. Sophorolipids production by Candida bombicola ATCC 22214 and its possible application in enhancing oil recovery. $4^{\text {th }}$. Internat Symp Appl Molec Microbiol Oil Syst (ISMOS) 2013; 15: 1-63.

[37] Konishi M, Fukuoka T, Morita T, Imura T, Kitamoto D. Production of new types of sophorolipids by Candida batistae. J Oleo Sce 2008; 57: 359-69. http://dx.doi.org/10.5650/jos.57.359

[38] Luna JM, Sarubbo L, Campos-Takaki GM. A new biosurfactant produced by Candida glabrata UCP 1002: characteristics of stability and application in oil recovery. Bra Arch Biol Technol 2009; 52: 63-9. http://dx.doi.org/10.1590/s1516-89132009000400001

[39] Kurtzman CP. Candida kuoi sp nov, an anamorphic species of the Starmerella yeast clade that synthesizes sophorolipid. Intern J System Evolut Microbiol 2012; 62: 2307-11. http://dx.doi.org/10.1099/ijs.0.039479-0

[40] Thaniyavarn J, Chianguthai T, Sangvanich P, Roongsawang $\mathrm{N}$, Washio K, Morikawa M, Thaniyavarn S. Production of sophorolipid biosurfactant by Pichia anomala. Biosc Biotech Biochem 2008; 72: 2061-8. http://dx.doi.org/10.1271/bbb.80166

[41] Solaiman DK, Ashby RD, Crocker NV. High-titer production and strong antimicrobial activity of sophorolipids from Rhodotorula bogoriensis. Biotech Prog 2015; 31: 867-74. http://dx.doi.org/10.1002/btpr.2101

[42] Saenge C, Cheirsilp B, Suksaroge ST, Bourtoo T. Potential use of oleaginous red yeast Rhodotorula glutinis for the bioconversion of crude glycerol from biodiesel plant to lipids and carotenoids. Proces Biochem 2011; 46: 210-8.

http://dx.doi.org/10.1016/j.procbio.2010.08.009

[43] Chen J, Song X, Zhang H, Qu Y, Miao J. Sophorolipid produced from the new yeast strain Wickerhamiella domercqiae induces apoptosis in $\mathrm{H} 7402$ human liver cancer cells. Applied Microbiol Biotech 2006; 72: 52-9. http://dx.doi.org/10.1007/s00253-005-0243-z

[44] Ma XJ, Li H, Song X. Surface and biological activity of sophorolipid molecules produced by Wickerhamiella domercqiae var sophorolipid CGMCC 1576. J Colloid Interface Sc 2012; 376: 165-72. http://dx.doi.org/10.1016/j.jcis.2012.03.007 
[45] Pattanathu KS, Rahman M, Gakpe E. Production, characterization and applications of biosurfactants. Review Biotech 2008; 7: 360-70. http://dx.doi.org/10.3923/biotech.2008.360.370

[46] Perfumo A, Rancich I, Banat IM. Possibilities and challenges for biosurfactants use in petroleum industry. In: Sen R editor. Biosurfactants' advances in experimental medicine and biology. 2nd ed. Berlin: Springer 2010; pp. 135-157. http://dx.doi.org/10.1007/978-1-4419-5979-9 10

[47] Goltapeh EM, Danesh YR, Varma A. Fungi as bioremediators. 1st ed. Berlin: Soil Biol, Springer; 2013. http://dx.doi.org/10.1007/978-3-642-33811-3

[48] Romero MC, Urrutia MI, Chiaravalli JC, Sabino G. Biosurfactant synthesis by wild yeasts able to degrade hydrocarbons. V Cong Soc Environ Toxicol Chem, SETAC Univ Nac Comahue 2014; p. 109.
[49] Joshi-Navare K, Khanvilkar P, Prabhune A. Jatropha oil derived sophorolipids: production and characterization as laundry detergent additive. Biochem Research Internat 2013; 2013: 1-11.

http://dx.doi.org/10.1155/2013/169797

[50] Hesham AE, Alamri SA, Khan S, Mahmoud ME, Mahmoud $\mathrm{HM}$. Isolation and molecular genetic characterization of a yeast strain able to degrade petroleum polycyclic aromatic hydrocarbons. Afr J Biotechl 2009; 8: 2218-23.

[51] Goulart GG, Coutinho JOPA, Monteiro AS, Siqueira EP, Santos VL. Isolation and characterization of gasolinedegrading yeasts from refined oil-contaminated residues. J Bioremed Biodeg 2014; 5: 1-9.

[52] Chandran P, Das N. Characterization of sophorolipid biosurfactant produced by yeast species grown on diesel oil. Intern J Sce Nature 2011; 2: 63-71.

Received on 09-12-2015

Accepted on 06-01-2016

Published on 02-03-2016

\section{DOI: http://dx.doi.org/10.6000/1927-3037.2016.05.01.4}

(C) 2016 Romero et al.; Licensee Lifescience Global.

This is an open access article licensed under the terms of the Creative Commons Attribution Non-Commercial License (http://creativecommons.org/licenses/by-nc/3.0/) which permits unrestricted, non-commercial use, distribution and reproduction in any medium, provided the work is properly cited. 